\title{
WACANA VISUAL ILUSTRASI KORUPSI DALAM RUBRIK OPINI KOMPAS PERIODE 2011
}

Noval Sufriyanto Talani, Iman Sujudi, dan Acep Iwan Saidi

Fakultas Teknik Universitas Gorontalo dan FSDR Institut Teknologi Bandung

Abstract.

Illustration is a visual language which is used by mass media for commenting news or hot issues which develop in society. Editorial illustration, for example, not only plays a role as an esthetic element at the rubric but also can describe its attitude and the media politic line in which it was published. During 2011 period, Kompas has been lightened up many corruption cases that still happen this day, not only through editorial illustration but also through an opinion article illustration. Both of those illustrations put out the opinion rubric in Monday-Saturday edition. This paper discusses the illustration meaning and its relation within the article, the ways in which the corruption's information was shown through illustration and the publics' interpretation to the corruption's illustration which was put on the opinion rubric at Kompas during 2011 period. To discover the answer of the problems that are investigated and to obtain the purpose which has been settled, this research uses qualitative approach with discourse analysis method. Through this research, a process model of visual discourse construction is also found.

Keyword: Corruption, Illustration, Opinion Rubric, Visual Discourse

\section{PENDAHULUAN}

Sebagai salah satu pemicu lahirnya gerakan reformasi, korupsi menarik perhatian serius dari berbagai kalangan termasuk media massa. Dalam kurun waktu tiga tahun terakhir pemberitaan tentang korupsi oleh media massa, baik cetak maupun elektronik mencerminkan semakin maraknya korupsi yang terjadi di Indonesia dengan berbagai modus dengan lintas generasi. Pemberitaan skandal Bank Century, suap cek pelawat, korupsi pejabat pemerintah dan penegak hukum, kasus korupsi wisma atlet dan Hambalang adalah sebagian dari peristiwa korupsi yang diberitakan media massa. Informasi yang diproduksi media massa untuk disampaikan kepada khalayak sasaran (pembaca) disajikan melalui tulisan dan seringkali disertai gambar sehingga dapat dilihat dan dibaca (Madjadikara, 2005: 12 dalam Triandjojo, 2008: 20). 
Ilustrasi merupakan gambar yang digunakan media cetak untuk menyampaikan pesan disamping pesan verbal. Dalam Dictionary of Media and Communication, gambar ilustrasi, figur, atau diagram yang digunakan untuk menjelaskan atau menghias sesuatu, terutama teks tertulis (Danesi, 2009: 154) Arnston (2006) berpendapat bahwa ilustrasi majalah dan surat kabar, selain berfungsi sebagai elemen estetis untuk artikel, juga untuk menyampaikan informasi tertentu dalam bentuk infografis. Pendapat lain mengenai ilustrasi, dikemukakan Ross (1963) seperti dikutip Aditia (2008: 25) menyatakan fungsi ilustrasi dalam sebuah tulisan awalnya merupakan gambar yang menjelaskan isi naskah, selain itu untuk memperindah penampilan rupa, dan juga untuk menambah daya tarik desain. Hal ini berarti bahwa ilustrasi merupakan pesan media yang ditampilkan secara visual dengan fungsi sebagai penyampai dan penjelas informasi, sebagai elemen estetis, dan menjadi daya tarik dalam desain.

Selain istilah ilustrasi, istilah karikatur maupun kartun juga digunakan untuk menyebut gambar yang ada dalam surat kabar. Karikatur mengandung art "sebagai gambar sindir (satire) serius sedangkan kartun hanyalah gambar lucu" (Sibarani, 2001; Sunarto, 2005: 4). Sumadiria (2009: 3) mengartikan karikatur "sebagai opini redaksi media dalam bentuk gambar yang sarat dengan muatan kritik sosial dengan memasukkan unsur kelucuan, anekdot, atau humor agar siapa pun yang melihatnya bisa tersenyum, termasuk tokoh atau objek yang dikarikaturkan itu sendiri."

Dari pendapat di atas dapat disimpulkan bahwa karikatur yang digunakan surat kabar merupakan informasi berupa gambar yang bersifat sindiran ataupun kritik yang dikemas secara lucu dan humor sehingga tidak membuat orang yang disindir atau dikritik menjadi emosi. Dalam makalah ini, penulis mengunakan istilah ilustrasi untuk mencakup istilah karikatur dan kartun yang dipahami sebagai pesan media dalam bentuk gambar (visual). Penggunaan ilustrasi tentu tidak terlepas dari fungsinya untuk memudahkan pembaca memahami pesan yang disampaikan media massa. Pesan yang dikomunikasikan melalui media gambar atau visual dapat diterima dengan cepat dan berkesan (Kusmiati, 1999). Hal ini menunjukkan bahwa pesan visual dapat menyederhanakan pesan verbal yang disampaikan atau dengan teknik tertentu lebih menguatkan pesan verbal dan meyakinkan khalayak.

Harian umum (HU) Kompas adalah salah satu media massa cetak yang menggunakan ilustrasi sebagai teks visual pembawa pesan yang terbit diberbaga rubriknya pada edisi Senin-Sabtu dan edisi Minggu. Rubrik Opini adalah salah satu rubrik yang rutin dan konsisten menampilkan ilustrasi bersamaan dengan teks opini yang dimuat. Rubrik Opini terbit pada edisi Senin-Sabtu. Dalam rubrik in terdapat lima ruang yang dibagi dalam dua halaman (6 dan 7), yakni ruang tajuk rencana (editorial), artikel opini, pojok, surat pembaca, dan iklan. Sebagai teks visual, ilustrasi yang dimuat dalam rubrik Opini berupa ilustrasi editorial dan ilustrasi artikel opini. Setiap edisi terbit Senin-Sabtu, selalu terdapat dua ilustrasi yang diterbitkan Kompas dalam rubrik Opini, baik itu ilustrasi editorial dengan ilustrasi artikel opini atau kedua-duanya adalah ilustrasi artikel opini yang diletakkan pada masing-masing halaman (lihat Gambar 1 dan Gambar 2).

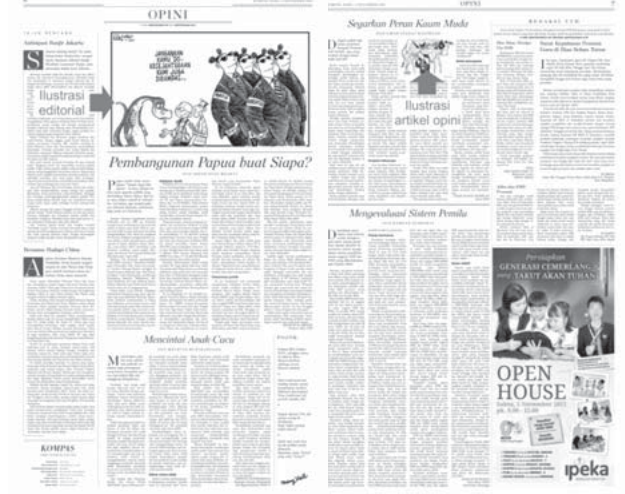

Gambar 1. Ilustrasi Editorial dan Ilustrasi Artikel Opini Sumber: capture screen dari situs http://epaper.kompas.com/epaperkompas.php?v=1.0 (Kompas Edisi Selasa, 2 November 2011 diakses 18 November 2011)

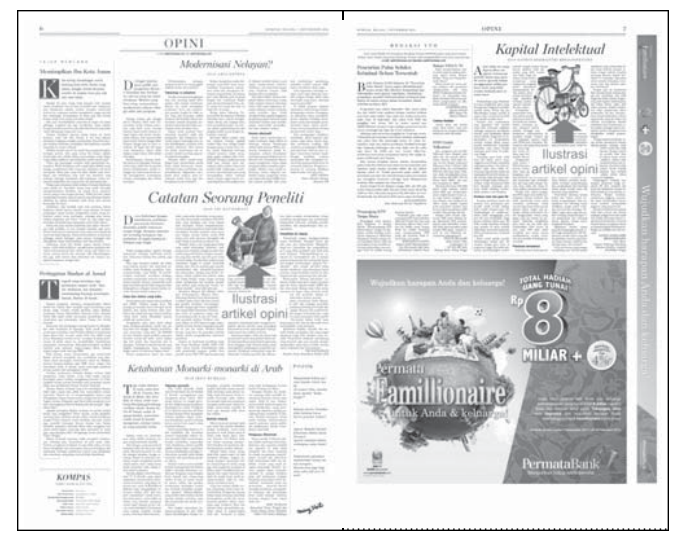

Gambar 2. Ilustrasi Artikel Opini

Sumber: capture screen dari situs http://epaper.kompas.com/epaperkompas.php?v=1.0 (Kompas Edisi Rabu, 1 November 2011 diakses 18 November 2011) 
Banyaknya opini korupsi yang dimuat Kompas membuktikan bahwa kasus-kasus tersebut mendapat perhatian masyarakat dan menjadi fenomena sosial di Indonesia saat ini. Beragam visualisasi ilustrasi telah diterbitkan Kompas untuk menggambarkan korupsi. Penggunaan tanda-tanda dalam ilustrasi untuk memvisualisasikan korupsi merupakan hasil penafsiran ilustrator Kompas terhadap suatu situasi yang sedang terjadi dan didasarkan pada isu-isu penting untuk dimuat. Rivers dkk. (2008: 228) mengemukakan bahwa peran media sebagai penafsir informasi memiliki kedudukan yang sama penting dengan perannya sebagai penyampai informasi. Hal ini menunjukkan, pesan dalan ilustrasi tidak terlepas dari konteks situasi yang berkembang di masyarakat dan penggunaan tanda-tanda sebagai pembawa pesan mewakili situasi yang diinformasikan. Selain itu, pemilihan sumber daya semiotik untuk menggambarkan peristiwa korupsi dapat menunjukkan sikap Kompas terhadap isu korupsi yang diopinikan.

Dari fakta di atas, menarik dan penting untuk dilakukan kajian mendalam mengenai ilustrasi korupsi yang dimuat Kompas pada rubrik opininya selama periode 2011 agar dapat mengetahui bagaimana media massa mewacanakan korupsi melalui visual. Menarik untuk menelaah penggunaan tanda-tanda yang memvisualisakan korupsi sebagai sebuah proses penyampaian informasi media massa kepada khalayak. Dan juga penting meneliti proses interpretasi khalayak terhadap infomasi yang mereka terima dari teks visual media massa.

Fakta ini memunculkan beberapa pertanyaan yang menarik untuk dikaji dan dibahas lebih mendalam, yakni: Bagaimana makna ilustrasi dan relasinya dengan artikel dalam rubrik Opini Kompas periode 2011?; Bagaimana informas korupsi ditampilkan dalam ilustrasi?; Bagaimana interpretasi khalayak pada ilustrasi korupsi yang dimuat Kompas di rubrik Opini selama periode 2011?

Penelitian ini akan membahas ketiga masalah tersebut secara runut agar dapat mengidentifikasi tanda-tanda yang digunakan untuk memvisualisasikan korupsi, mendes-kripsikan makna ilustrasi, mengetahui relasi antarteks, mengetahui posisi ilustrasi dalam rubrik, mengetahui nilai informasi yang ditampilkan dalam ilustrasi, dan mengetahui dan memahami cara khalayak menginter-pretasi teks visual media massa khususnya ilustrasi korupsi yang dimuat dalam rubrik Opini Kompas selama periode 2011

\section{METODE PENELITIAN}

Penelitian ini secara umum adalah penelitian seni rupa dan desain yang menjadikan ilustrasi sebagai objek kajian agar menghasilkan sebuah deskrips pemahaman mendalam tentang ilustrasi di media massa khususnya dalam rubrik opini. Sehingga pendekatan yang digunakan dalam penelitian ini adalah pendekatan kualitatif dengan metode analisis wacana. Dari data teks visual (ilustrasi) yang terkumpul, terdapat 74 ilustrasi korupsi yang diterbitkan Kompas dalam rubrik Opini selama periode 2011. Ilustrasi-ilustrasi tersebut dikelompokkan ke dalam tujuh tema, tapi dalam makalah ini yang dibahas hanya satu tema saja, yaitu tema korupsi makin sempurna. Analisis teks visual dilakukan dengan dua tahap. Tahap pertama adalah analisis visual. Tahap ini dilakukan untuk mencari makna ilustrasi, menemukan relasi antarteks (visual/ilustrasi dan verbal/artikel). Dan tahap kedua adalah analisis wacana yang diambil dari data hasil perbincangan dengan 11 orang khalayak melalui diskusi kelompok fokus (10 orang mahasiswa) dan wawancara (seorang kartunis).

Makna yang diungkap melalui analisis visual mengikuti Kress dan van Leeuwen yang memandang sebuah gambar dalam komunikasi visual memiliki tata bahasa yang mereka sebut dengan "tata bahasa visual". Cara elemen-elemen visual digambarkan —orang, tempat dan hal lainnya-menggabungkan pernyataanpernyataan visual yang memiliki kompleksitas lebih besar atau lebih rendah dan ekstensinya adalah cara penjelasan dalam tata bahasa visual, sama seperti bahasa yang menggambarkan bagaimana kata-kata menggabungkan klausa, kalimat dan teks (Kress dan van Leeuwen, 2006: 1). Menurut keduanya, banyak studi yang mengabaikan tentang "tata bahasa visual." Dalam tata bahasa visual Kress dan van Leeuwen, mencari makna sebuah desain visual dapat diperoleh melalui makna representasional yang melihat struktur naratif dan struktur konseptual, makna interaktif yang menelaah jarak, kontak antar partisipan, dan point of view, serta makna komposisi yang melihat nilai informasi, pembingkaian, dan ciri khas dalam visual. Ketiga makna itu yang membentuk makna sebuah desain visual. Sama seperti Kress dan van Leeuwen, Neil Cohn juga memandang visual sebagai sebuah bahasa disamping bahasa verbal (yang ditandai dengan suara) dan bahasa nonverbal (yang ditandai dengan gerakan). Bahkan lebih jauh Cohn (2007: 35) dalam makalahnya Visual Lexicon membahas berbagai tingkat representasi dalam bahasa visual dengan tujuan mencari arti yang dimiliki item leksikal visual yang secara spesifik bahasa visual komik.

Wacana dalam penelitian ini dipahami sebagai pemroduksian gagasan, tema, topik atau konsep yang memiliki dampak pada perubahan struktur sosial. Sebuah opini yang diterbitkan media massa menjadi contoh bagaimana sebuah gagasan, topik atau tema yang diproduksi dan pada akhirnya membawa dampak perubahan ketika opini tersebut membentuk pemahaman sosial. Pada analisis visual, makna yang dihasilkan berdasarkan interpretasi peneliti terhadap objek visual ilustrasi yang ditelaah sebagai bentuk praktik kewacanaan melalui pemroduksian teks (wacana) oleh media massa. Sedangkan pada analisis wacana ini, makna yang dihasilkan berdasarkan interpretasi terhadap hasil perbincangan khalayak mengenai visual ilustrasi opini sebagai bentuk praktik sosial melalui pengonsumsian teks (wacana). Manusia mempersepsi dan menafsirkan objek dan 
peristiwa dalam sistem makna tergantung pada struktur diskursif, karena melalui struktur diskursif ini, objek dan peristiwa menjadi nyata (Eriyanto, 2009: 73).

Wacana dalam pandangan Fairclough menekankan adanya hubungan dialektik dengan dimensi-dimensi sosial lainnya. Di mana "wacana merupakan bentuk penting praktik sosial yang mereproduksi dan mengubah pengetahuan, identitas dan hubungan sosial yang mencakup kekuasaan dan sekaligus dibentuk oleh struktur dan praktik sosial lainnya" (Jorgensen dan Phillips, 2007: 122-123) Meskipun dalam penelitian ini menggunakan model analisis wacana dari Fairclough, akan tetapi pada interpretasi teks visual, metode analisisnya seperti telah dikemukakan sebelumnya. Sehingga kerangka analisis dalam penelitian ini merupakan pengembangan dari model analisis wacana Fairclough yang penelit sebut dengan kerangka analisis wacana visual dan penerapannya bersifat kontekstual (pada penelitian tesis ini). Model kerangka analisis wacana visual tersebut dapat digambarkan sebagai berikut:

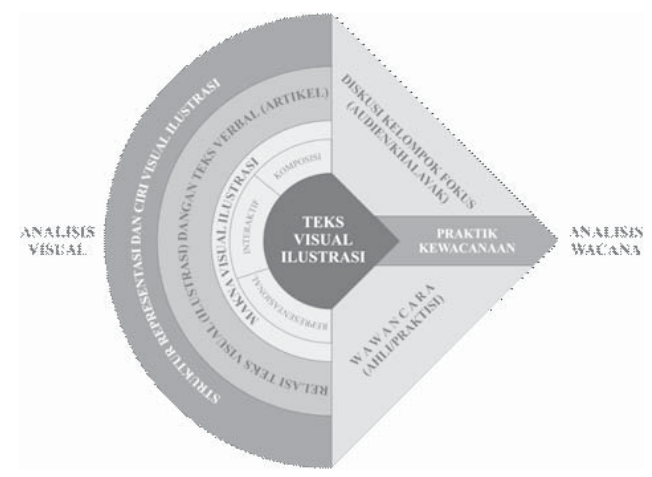

Gambar 3. Kerangka Analisis Wacana Visual

\section{KAJIAN TEORI}

Teori yang digunakan sebagai rujukan adalah teori wacana yang dikemukakan Ernesto Laclau dan Chantal Mouffe dan teori wacana kritis yang dikemukakan Norman Fairclough. Istilah wacana dalam teori wacana Laclau dan Mouffe adalah satu dari dua konsepnya, yakni wacana dan medan kewacanaan. Istilah wacana digunakan untuk makna yang ditetapkan secara parsial. Sedangkan medan kewacanaan merupakan surplus makna, peniadaan segala sesuatu dari wacana khusus (Jorgensen dan Phillips, 2007: 107). Dalam konsep teoretis Laclau dan Mouffe ada empat hal yang saling berhubungan, yakni artikulasi, wacana, momen, dan unsur.
Pemikiran Fairclough tentang analisis wacana kritis sangat dipengaruhi oleh pemikiran Halliday, Fowler, dan Foucault. Dalam pandangan kritis, wacana dibangun dari teks dan konteks. Di mana "teks dipandang secara dinamis sebagai komunikasi interpersonal dalam konteks." Hal ini berarti teks sebagai medium wacana. Penggambaran teks dan konteks secara bersama-sama dalam suatu proses komunikasi adalah fokus perhatian analisis wacana, karena wacana diproduksi, dimengerti, dan diinterpretasi dalam konteks tertentu (Santoso, 2008: 10-12). Konsep wacana Fairclough menitikberatkan pada praktik sosial, karena menurutnya pengetahuan, identitas, dan hubungan sosial diproduksi dan diubah secara sosial, sehingga "wacana memiliki hubungan dialektik dengan dimensidimensi sosial lainnya" termasuk praktik "jurnalisme dan hubungan masyarakat" bersifat kewacanaan (Jorgensen dan Phillips, 2007: 122-123).

Berbeda dengan Laclau dan Mouffe yang memandang semua praktik sosial adalah wacana, Fairclough membatasi istilah wacana pada sistem semiotik bahasa dan pencitraan. Pengonstruksian identitas sosial, hubungan sosial, dan sistem pengetahuan dan makna merupakan kontribusi yang diberikan oleh wacana. Selain teori wacana, teori komunikasi juga digunakan untuk melihat proses komunikasi yang termediasi khususnya cara media menyampaikan pesan kepada khalayak. Menurut Sobur (2009: 48) merumuskan analisis wacana sebagai "studi tentang struktur pesan dalam komunikasi." Dalam semiotika sosial, dunia yang dikonstruksi secara sosial direpresentasikan melalui bentuk-bentuk bahasa yang terkodekan. Menurut Theo van Leeuwen, membahas semiotika sosial berkaitan erat dengan dua isu, yaitu sumber daya material komunikasi dan cara penggunaannya diatur secara sosial.

Dari pandangan ini van Leeuwen mendefinisikan wacana dengan perhatiannya pada bentuk jamak, dimana wacana sebagai pengetahuan sosial dibangun dari beberapa aspek realitas. Dengan konstruksi sosial, pengetahuan telah dikembangkan dalam konteks sosial tertentu, dan dengan cara yang sesuai dengan kepentingan para pelaku sosial dalam konteks ini (van Leeuwen, 2005: 93). Perspektif resepsi mengonsep-tualisasikan khalayak sebagai yang aktif dan teks sebagai yang tidak menentu, dan makna dipandang sebagai milik teks dan pembaca. Hal ini memberi gagasan bahwa makna adalah sesuatu yang dibuat, atau dibentuk dalam interaksi teks dan pembaca (Barbatsis dalam Ken dkk., 2005: 271).

Kehadiran ilustrasi bersamaan dengan teks artikel dalam rubrik Opini Kompas merupakan intertekstualitas yang membentuk wacana media. Intertekstualitas mengacu pada cara bahwa makna dari setiap gambar atau teks satu diskursif tidak hanya tergantung pada satu teks atau gambar, tetapi juga pada makna yang dibawa oleh gambar lain dan teks (Rose, 2001: 137). Intertekstualitas dalam pandangan Fairclough yang mengembangkan pemikiran Julia Kristeva dan Michael Bakhtin mengemukakan bahwa istilah intertekstualitas adalah "teks dan 
ungkapan dibentuk oleh teks yang datang sebelumnya, saling menanggapi dan salah satu bagian dari teks tersebut mengantisipasi lainnya" (Eriyanto, 2009: 305).

Perkembangan teknologi cetak masa kini mendorong produksi intertekstualitas dalam media massa menjadi hal yang lumrah. Mengadops konsep intertekstualitas di atas, kehadiran teks visual (ilustrasi) dan teks verba (tulisan) dalam rubrik Opini Kompas adalah contoh bagaimana kedua teks tersebut disandingkan dalam satu medium. Visual ilustrasi dalam penelitian tesis ini dapat dipahami sebagai kode visual yang digunakan Kompas dalam rubriknya untuk memberikan informasi kepada khalayak (pembaca). Dalam konteks wacana visual, ilustrasi tersebut mengartikulasikan berbagai wacana-wacana yang dibangun oleh media massa. Kode-kode visual yang digunakan pada ilustras merupakan hasil interpretasi terhadap suatu fenomena yang terjadi dalam praktek sosial tertentu. Melalui kode ini diharapkan khalayak pembaca dapat mengetahui dan memahami peristiwa yang sedang digambarkan.

\section{HASIL DAN PEMBAHASAN}

Untuk mengungkap makna ilustrasi, pembacaan visualnya merujuk pada pendapat Kress dan van Leeuwen mengenai makna dalam tata bahasa visual. Mengikuti pendapat keduanya, makna yang diungkap adalah makna representasional, makna interaksi, dan makna komposisi yang tampil dalam desain visual ilustrasi. Untuk mencari makna representasional menurut Kress dan van Leeuwen (2006: 45) dapat ditelusuri melalui struktur naratif dan struktur konseptual visual ilustrasi. Makna interaksi dibentuk oleh adanya kontak dan jarak antara partisipan dengan viewer serta adanya point of view dalam ilustrasi Sedangkan makna komposisi dapat diungkap dari nilai informasi, ciri khusus, dan pembingkaian (framing) yang terdapat dalam ilustrasi. Makna-makna in kemudian direlasikan untuk memperoleh makna keseluruhan dari ilustrasi. Pembacaan ilustrasi bukan hanya sekedar melihat objek apa yang digambar, tetap juga melihat bagaimana objek itu digambarkan atau oleh Tabrani (2005:9) disebut dengan wimba (imaji yang kasat mata). Dalam wimba, kata Tabrani, selalu terdapat isi wimba (apa yang digambar) dan cara wimba (cara objek gambar itu digambar). Sebagai sebuah karya rupa, ilustrasi tentu pula memiliki isi wimba dan cara wimba. Walaupun dalam analisis membaca wimba, tetapi pengungkapan makna tetap mengacu pada pandangan Kress dan van Leeuwen.

\section{Tema: Korupsi Makin Sempurna}

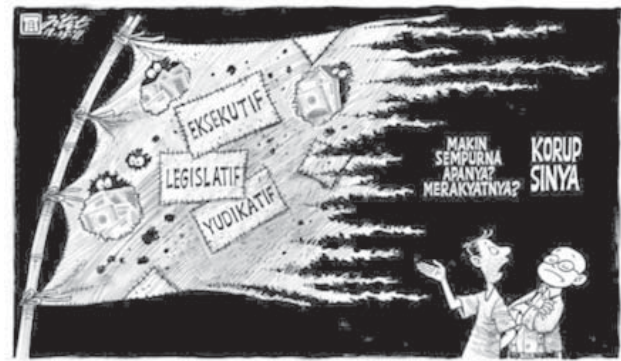

Gambar 4. Ilustrasi Editorial Karya Jitet

Sumber: capture screen dari situs http://epaper.kompas.com/epaperkompas.php?v=1.0 (Kompas Edisi 18 Mei 2011 diakses 24/02/2011)

Ilustrasi editorial karya Jitet ini dimuat Kompas pada edisi Rabu, $18 \mathrm{Mei}$ 2011. Dalam ilustrasi terdapat dua tata ungkap yang digunakan ilustrator untuk menyampaikan pesan, yaitu tata ungkap verbal dengan memanfaatkan tulisan atau huruf dan tata ungkap visual (gambar). Tata ungkap visual sangat dominan dalam ilustrasi yang terdiri dari elemen bidang segi empat dengan tonal gelap sebagai latar belakang, tiang bendera dari bambu, bendera yang penuh tambalan, lubang, dan robek terlihat sedang berkibar, dibalik bendera terdapat lembaran uang dan siluet figur anonim dengan beberapa mata melihat kearah lembaran uang, dan dua figur orang sedang berbicara. Sedangkan tata ungkap verbal terdapat pada tiga buah tambalan bendera dengan tulisan "EKSEKUTIF", "LEGISLATIF", "YUDIKATIF" pada masing-masing tambalan, teks dialog "MAKIN SEMPURNAAPANYA? MERAKYATNYA?" dan "KORUPSINYA."

Tata ungkap visual dan verbal adalah elemen-elemen yang dihadirkan ilustrator untuk membawa pesan massa. Kehadiran keduanya bukan untuk saling meniadakan melainkan saling mendukung agar pesan menjadi mudah dipahami. Akan tetapi, cara elemen-elemen tersebut dihadirkan juga menjadi penting untuk diketahui, karena bagi Tabrani, visual bukan hanya dilihat dari apa yang ditampilkan, tetapi juga bagaimana ia ditampilkan. Dalam kartun, makna akan terbangun dari dialog gambar dan tulisan (Sunarto, 2005: 27).

Pada ilustrasi editorial di atas, kehadiran bendera yang berkibar dengan segala informasi di dalamnya menjadi penting bagi kehadiran dua figur orang disampingnya. Karena dengan kehadiran bendera tersebut, konteks pembicaraan kedua figur dapat diketahui. Jadi, struktur naratif ilustrasi dimulai dari bendera yang bertuliskan "EKSEKUTIF", "LEGISLATIF", "YUDIKATIF" sebagai 
tambalan, memiliki banyak lubang dan pada tiga lubang yang besar terdapa lembaran uang sedangkan dibaliknya terdapat siluet figur anonim dengan mata seperti sedang mengamati. Teks "MAKIN SEMPURNA APANYA? MERAKYATNYA?" dan teks "KORUPSINYA" merupakan pernyataan dar masing-masing figur di bawah teks tersebut. Kedua figur memperlihatkan ekspres wajah dan sikap yang berbeda. Figur 1 terkesan sangat serius dengan ucapannya, sedangkan figur 2 terkesan datar atau santai menanggapinya. Dari pernyataan kedua figur ini pula diketahui bahwa yang menjadi topik perbincangan keduanya adalah persoalan korupsi yang makin sempurna.

Persoalan korupsi yang diperbincangkan kedua figur sebenarnya mengarah pada informasi yang terdapat dalam bendera. Antara figur dan bendera dihubungkan oleh sebuah vektor, dimana kedua figur orang (partisipan dari mana vektor berasal) berperan sebagai aktor dan bendera (partisipan dimana titik vektor) berperan sebagai tujuan (Kress dan van Leeuwen, 2006: 50). Yang menjadi vektor dalam ilustrasi di atas adalah posisi tangan figur 1 yang mengarah ke bendera. Vektor ini yang menjadi struktur konseptual dari ilustrasi. Penanda "EKSEKUTIF", "LEGISLATIF", "YUDIKATIF" merepresentasikan tiga lembaga negara yang menjadi pilar demokrasi. Ketiga lembaga ini yang menjadi rujukan atas perbincangan kedua figur mengenai makin sempurnanya korupsi. Jadi, dari penanda teks tersebut dapat dipahami bahwa bendera usang yang berlubang, penuh tambalan, dan robekan yang semakin mendekati pangkalnya adalah sebagai metonimi dari sebuah negara yang sedang mengalami kerusakan dan pengeroposan pada pilar-pilarnya karena korupsi. Maka makn representasional dari ilustrasi adalah korupsi yang dilakukan tiga lembaga negara (Eksekutif, Legislatif, Yudikatif) menjadikan korupsi di negeri ini semakin sempurna.

Sebuah gambar bukan hanya harus mampu merepresentasikan sesuatu, melainkan juga dapat menciptakan hubungan interaktif dengan pengamat atau viewer. Menurut Kress dan van Leeuwen (2006: 149) makna interaktif dari sebuah gambar dapat dilihat dari tiga dimensi, yaitu kontak, jarak sosial, dan sikap. Kontak yang tercipta dalam ilustrasi adalah sebuah penawaran. Kontak ini terjadi karena partisipan mewakili terutama figur orang tidak menatap kearah viewer Begitu pula dengan figur-figur anonim dibalik bendera, lirik matanya tidak mengarah ke viewer. Namun demikian, bahasa tubuh figur dan kontras pada soro mata figur anonim menawarkan terjadinya kontak dengan viewer. Penggambaran dua figur orang secara medium shot menjadikan elemen tersebut sebagai sumbe daya interaktif dari (sikap) gambar subjektif, maka jarak antara viewer da partisipan mewakili adalah jarak dekat sosial. Jarak dekat sosial adalah jarak dimana kita dapat melihat orang lain dari pinggang ke atas atau sebagai jarak personal jauh seperti kata Hall (dalam Kress dan van Leeuwen, 2006: 125).
Sikap yang ditunjukkan oleh kedua figur dalam ilustrasi sebenarnya dapat mewakili sikap masyarakat yang merasa skeptis dengan semakin maraknya korupsi yang melibatkan lembaga-lembaga negara. Sikap figur 2 dapat menjadi representasi dari sikap masyarakat tersebut. Teks "MERAKYATNYA?" menjadi representasi dari harapan masyarakat agar para pejabat negara lebih memerhatikan dan mendekatkan dirinya dengan rakyat, tetapi yang terjadi justru sebaliknya, mereka terjebak pada tindakan korupsi. Ukuran bendera yang relatif besar dibanding elemen visual lainnya, maka bendera menjadi point of view dari elemen visual dan informasi yang dibawanya menjadi penting. Sedangkan tulisan "KORUPSINYA" adalah point of view dari elemen verbal. Semakin rusaknya bendera yang sedang berkibar ditandai oleh banyaknya lubang, tambalan, dan robekan-robekan pada kain bendera memberi makna interaktif bahwa negara mengalami kerusakan dan kehancuran disebabkan makin meluasnya korupsi yang menjangkiti lembaga-lembaga negara (Eksekutif, Legislatif, dan Yudikatif). Korupsi terus merong-rong dan menghantui eksistensi negara melalui lembaga perwakilannya.

Makna komposisi berkaitan dengan makna representasional dan interaktif dalam ilustrasi yang satu sama lain melalui tiga sistem yang saling terkait, yaitu nilai informasi, ciri khusus, dan pembingkaian (Kress dan van Leeuwen, 2006: 177). Penggambaran tiang bendera yang miring menjadikan komposisi dalam ilustrasi tidak seimbang dan terkesan tidak stabil. Kemiringan ini memperlihatkan adanya angin yang sangat kencang menerpa bendera. Dengan ukuran yang relatif besar, nilai informasi dalam bendera menjadi sangat dominan dan sorotan dalam ilustrasi. Ketidakteraturan penyusunan tambalan (Eksekutif, Legislatif, Yudikatif) menambah kesan ketidakstabilan pada masing-masing lembaga yang direpresentasikan. Dalam ilustrasi terdapat metafora segar (lihat Sunarto, 2005: 125) pada elemen bendera. Teks "EKSEKUTIF, LEGISLATIF, dan YUDIKATIF" sebenarnya merupakan kendaraan yang digunakan ilustrator untuk mengalihkan pernyataan "MAKIN SEMPURNA." Kalimat tanya "MAKIN SEMPURNA APANYA?" menjadi petunjuk bahwa ada kalimat "MAKIN SEMPURNA" hadir sebelumnya. Misalnya, teks "EKSEKUTIF, LEGISLATIF, dan YUDIKATIF" tidak digunakan, maka dapat dipastikan nilai informasi dalam ilustrasi menjadi berkurang. Dan apa yang membuat korupsi makin sempurna menjadi tidak jelas. Di sini kehadiran teks "EKSEKUTIF, LEGISLATIF, dan YUDIKATIF" jadi nilai informasi spesifik dan signifikan dari ilustrasi.

Ilustrasi editorial karya Jitet di atas memiliki ciri khusus dalam komposisinya. Walaupun figur orang ditampilkan dengan medium shot, penempatannya dalam komposisi berada di latar depan, kemudian disusul visualisasi bendera, dan latar belakang gelap. Melalui ukurannya yang lebih besar, objek bendera menjadi ciri menonjol dari ilustrasi. Pembingkaian dilakukan 
illustrator melalui pesan yang disampaikan. Pertama, pembingkaian pesan dalam bendera. Kedua, pembingkaian dua figur orang dan pesan teks dialognya Selanjutnya kedua pembingkaian pesan itu disatukan ke dalam satu pembingkaian gambar dengan hadirnya latar belakang gelap. Dari komposisi di atas, maka makna ilustrasi adalah semakin maraknya korupsi yang melibatkan Eksekutif, Legislatif, dan Yudikatif membuat negara tersandera oleh korupsi itu sendiri dan membuat masa depan negara semakin suram.

Berdasarkan uraian di atas, maka konteks situasi yang digambarkan dalam ilustrasi adalah korupsi telah merambah lembaga-lembaga negara, baik lembaga pemerintahan (Eksekutif), lembaga perwakilan rakyat (Legislatif), dan lembaga penegak hukum (Yudikatif). Keterlibatan ketiga lembaga negara itu tentu membawa dampak kerusakan pada keberlangsungan kehidupan bernegara karena ketiga lembaga negara tersebut menjadi pilar penyelenggaraan negara. Perhatian dan kepedulian terhadap rakyat seharusnya menjadi landasan penyelenggaraan negara, tetapi yang terjadi justru korupsi telah menggerogoti lembaga yang seharusnya menjadi pilar demokrasi yang bersih dari korupsi.

\section{Relasi Ilustrasi dengan Teks Artikel dalam Rubrik Opini}

Di atas telah diuraikan makna yang terungkap dibalik ilustrasi, baik itu makna representasional, makna interaktif maupun makna komposisi. Maknamakna tersebut membantu untuk melihat relasi antara ilustrasi sebagai teks visua dengan artikel sebagai teks verbal. Pada bagian ini dibahas juga beberapa ilustras yang masuk dalam kelompok tema "Korupsi Makin Sempurna". Hal ini dilakukan agar dapat mengetahui bagaimana ilustrasi dan artikel itu terhubung dan juga mengetahui elemen apa yang digunakan dalam visual ilustrasi untuk menggambarkan relasinya. Karena ilustrasi-ilustrasi yang dikaji tak memilik caption, maka untuk memudahkan pembahasan, penyebutan ilustrasi berdasarkan nomor pada tabel yang telah dibuat. Selain itu, layout pada setiap artikel (tajuk rencana dan artikel opini) dibagi ke dalam lima bagian untuk membantu mengetahui di bagian mana relasi itu tercipta. Kelima bagian itu antara lain judul, lead, pengantar/pendahuluan, isi/pembahasan, dan penutup. Yang dimaksud dengan lead adalah paragraf pertama artikel yang biasanya ditandai dengan adanya drop cap. Pengantar/pendahuluan adalah satu atau dua paragraf setelah lead Sedangkan yang dimaksud penutup adalah satu atau dua paragraf terakhir. Selain itu dianggap sebagai isi/pembahasan artikel.
Tabel 1 Ilustrasi Editorial dan Ilustrasi Artikel dengan Tema "Korupsi Makin Sempurna"

\begin{tabular}{|c|l|l|c|}
\hline No & \multicolumn{1}{|c|}{ Kategori Ilustrasi } & \multicolumn{1}{|c|}{ Edisi Terbit } & Ilustrator \\
\hline 1 & Ilustrasi Editorial & Rabu, 18 Mei 2011 & Jitet \\
\hline 2 & Ilustrasi Editorial & Rabu, 23 Februari 2011 & Jitet \\
\hline 3 & Ilustrasi Editorial & Rabu, 15 Juni 2011 & Jitet \\
\hline 4 & Ilustrasi Editorial & Rabu, 28 Desember 2011 & Jitet \\
\hline 5 & Ilustrasi Editorial & Rabu, 9 November 2011 & Handining \\
\hline 6 & Ilustrasi Artikel Opini & Sabtu, 12 November 2011 & Jitet \\
\hline 7 & Ilustrasi Artikel Opini & Senin, 12 September 2011 & Jitet \\
\hline 8 & Ilustrasi Artikel Opini & Sabtu, 15 Januari 2011 & Jitet \\
\hline 9 & Ilustrasi Artikel Opini & Jumat, 11 Februari 2011 & Didie SW \\
\hline 10 & Ilustrasi Artikel Opini & Rabu, 9 November 2011 & Didie SW \\
\hline
\end{tabular}

Dari tabel di atas diketahui bahwa edisi terbit ilustrasi-ilustrasi tersebut, yaitu edisi Senin, Rabu, Jumat, dan Sabtu. Adapun ilustratornya antara lain Jitet, Handining, dan Didie SW.

Berdasarkan makna yang terungkap, ilustrasi no 1 di atas memiliki relasi dengan artikel tajuk rencana "Melihat Lagi Reformasi” dan artikel opini "Korupsi dan Demokrasi" (Kompas 18/05/2011). Relasi ilustrasi dengan artikel tajuk rencana tercipta melalui isi/pembahasan artikel. Hal ini dapat dilihat dari pembahasannya mengenai lahirnya reformasi yang ditandai oleh berakhirnya Orde Baru yang dipimpin Soeharto karena dituduh korup, sehingga elite politik saat itu "berupaya mendesain Indonesia yang demokratis dan bersih dari korupsi." Redaksi juga menyoroti persoalan mengenai banyaknya lembaga baru yang terbentuk pasca reformasi, namun tidak membawa banyak manfaat bagi masyarakat karena dibentuk tanpa desain dan korupsi juga tak berkurang. Sedangkan relasi ilustrasi dengan artikel opini terlihat hampir disemua bagian artikel, kecuali dibagian lead tidak terlihat relasinya. Di bagian pengantar/ pendahuluan artikel terlihat jelas dari uraian penulis tentang terus tumbuhnya korupsi yang dibarengi oleh rendahnya kepercayaan masyarakat terhadap akuntabilitas dan kinerja lembaga demokrasi khsusunya lembaga politik (parpol dan parlemen) dan juga lembaga hukum. Penulis memberi contoh terkuaknya kasus korupsi di Kemenpora yang melibatkan pejabat Kemenpora, anggota dewan sekaligus petinggi partai Demokrat, menjadi fenomena kian mapannya korupsi politik.

Makin masifnya korupsi yang melibatkan berbagai lembaga demokrasi, menjadikan negara dalam bahaya korupsi yang tak terkendali. Terkadang kasuskasus korupsi menjadi komoditas politik di lembaga Legislatif, sesaat mencuat 
kepermukaan, kemudian hilang begitu saja atau tergantikan oleh kasus-kasus lainnya. Fenomena ini membuat penulis artikel menilai, bahwa setelah 13 tahun reformasi, "reformasi birokrasi dan politik gagal menyingkirkan rezim korupsi, tetapi hanya mentransformasi bentuk korupsi seiring perubahan struktu kekuasaan pasca-Pemilu 1999.” Dengan mengutip pendapat Vedi Hadiz, penulis menyatakan "kelembagaan demokrasi produk reformasi telah dibajak elite predator". Dibagian akhir penulis menutup dengan pernyataan:

Apabila korupsi jadi bahan bakar utama untuk menggerakkan mesin demokrasi, dalam jangka panjang keadaan ini akan melanggengkan sistem yang korup. Indonesia bahkan bisa terpuruk dalam situasi yang lebih kleptokratik, yaitu para penguasa merampok dengan lahap kekayaan negaranya sendiri, bergelimang kemewahan di tengah rakyatnya yang miskin (Kompas 18/05/2011).

Berdasarkan uraian di atas dapat diketahui bahwa ilustrasi editorial yang dimuat bersamaan dengan artikel-artikel tersebut memiliki hubungan untuk saling melengkapi dan menguatkan. Sehingga posisi ilustrasi tersebut dalam rubrik Opini Kompas menjadi pelengkap dan penguat artikel. Ilustrasi menjadi pelengkap pesan bagi artikel tajuk rencana, sedangkan untuk artikel opini, ilustrasi menjad penguat pesannya. Hal ini terlihat dari elemen visual tambalan bendera yang merepresentasikan lembaga-lembaga demokrasi (Eksekutif, Legislatif, Yudikatif). Begitu pula dengan visualisasi bendera yang robek, berlubang dan penuh tambalan menjadi penguat pesan artikel dibagian penutup sebagaimana kutipan di atas. Sedangkan penggunan latar belakang gelap dan adanya visual siluet mata dibalik bendera dapat menguatkan pesan dari pembajakan oleh eliteelite predator pada kelembagaan demokrasi yang ada.

Selain ilustrasi no 1 yang menggambar-kan makin sempurnanya korupsi dengan melibatkan berbagai lembaga negara. Beberapa ilustrasi (editorial dan artikel) juga menampilkan korupsi yang dilakukan oleh lembaga negara. Seperti ilustrasi no 2 (Kompas 15/06/2011) mengungkap meluasnya korupsi lewat dialog antara partisipan mewakili dengan menggunakan tiga panel gambar. Dalam dialog, yang disoroti oleh figur 1 adalah persoalan pemerataan dan ditanggapi oleh figur 2 bahwa pemerataan sudah terjadi, yakni merata “KORUPSINYA!". Ilustras ini tidak memiliki hubungan dengan artikelnya, baik dengan artikel tajuk rencana maupun artikel opini. Sehingga posisi ilustrasi dalam rubrik sebagai pesan yang berdiri sendiri. Lain lagi dengan ilustrasi no 3, melalui tiga panelnya, ilustrasi in mengungkap pesan tentang merajalelanya korupsi tetapi mendapatkan tanggapan dingin dari penguasa. Namun, ketika dikatakan kursi(kekuasaan)nya miring langsung mendapat respons serius. Ilustrasi ini menjadi gambaran bahwa korupsi bukan lagi sesuatu yang mendapat tanggapan serius dibanding dengan kekuasaan. Apalagi adanya artikel opini "Bongkar Tuntas Korupsi Yudisial" dan "Kepala Daerah Kok Masih Korupsi?" memperlihatkan relasinya dengan ilustrasi. Artikelartikel tersebut menguraikan korupsi yang dilakukan oleh kekuasaan yudikatif dan eksekutif. Dari relasi yang terbangun, ilustrasi menempati posisi sebagai pelengkap dan penguat pesan artikel opini khususnya artikel kedua.

Pada ilustrasi no 4 digambarkan seorang figur berjas yang berkepala uang kertas memegang garpu dan dan tameng yang terdapat lembaran-lembaran uang dan bertuliskan "Oknum" sedang duduk menindih tengkorak dengan sebuah papan bertuliskan "HAM". Di depannya terdapat meja yang di atasnya ada potongan tanah, rumah, dan pepohonan. Dua figur orang di bawahnya memperlihatkan ekspresi heran dan terkejut melihat perilaku figur di depannya. Ilustrasi ini sangat erat hubungannya dengan artikel opini yang berjudul "Pembangunan dan Korupsi" (Kompas 28/12/2011). Hubungan terjadi di bagian isi/pembahasan artikel terutama pembahasan yang menyoroti masalah HAM, sehingga elemen visual papan yang bertuliskan HAM menjadi penanda hubungan antara ilustrasi dengan teks artikel. Dari hubungan tersebut, maka posisi ilustrasi dalam rubrik sebagai penguat pesan artikel sekaligus mengamplifikasi pesan dengan adanya elemen visual tengkorak, uang kertas menjadi kepala, dan adanya potongan tanah, rumah, dan pepohonan yang seolah-olah siap "disantap".

Ilustrasi-ilustrasi di atas adalah ilustrasi editorial, sehingga tidak mutlak harus berhubungan langsung dengan artikel. Sedangkan ilustrasi artikel opini selalu terkait dengan artikelnya. Dari hasil temuan, pada tema ini terdapat beberapa ilustrasi artikel opini yang menampilkan korupsi di lembaga-lembaga negara terutama korupsi di lembaga eksekutif. Seperti ilustrasi no 8 (Kompas 15/01/2011) menggunakan visualisasi buku sebagai metafora visual dari pengetahuan/pendidikan karena artikel opini yang dimuat membahas tentang bantuan operasional sekolah dengan judul artikel "Skandal Dana BOS". Sebagai bentuk metafora, hubungan ilustrasi terlihat hampir disemua bagian layout artikel, baik judul, lead, pengantar, isi, dan penutup. Ilustrasi ini mengamplifikasi pesan dalam artikel, sebab secara konotatif, ilustrasi dapat dimaknai sebagai buruknya dunia pendidikan yang menjadi lahan korupsi bagi pengelolanya yang ditandai oleh visualisasi bentuk buku seperti celengan dan penuh dengan lubang tikus.

Begitu pula dengan ilustrasi no 9 (Kompas 11/02/2011). Dengan artikel opini berjudul "Halo 'Rekening Gendut", divisualisasikan dengan sebuah brankas uang yang melebihi kapasitas sampai salah satu lembar uangnya menyendul keluar dibalik celah brankas. Elemen visual gembok dan rantai mengindikasikan bahwa isi brankas tersebut berusaha ditutup-tutupi. Melihat visualisasinya, ilustrasi masih menjadi metafora visual dari rekening gendut. Karena brankas memiliki fungsi sebagai tempat penyimpanan uang dan gambarnya terlihat melebihi 
kapasitas, maka dapat disimpulkan bahwa kata rekening gendut menjadi rujukan dari ilustrasi. Ilustrasi ini memiliki hubungan yang kuat dengan judul dan penutup artikel karena judul dan kalimat terakhir artikel sama, yakni "Halo, Rekening Gendut!". Jadi posisi ilustrasi ini sebagai penguat pesan dari artikel karena artike tersebut menyoroti kepemilikan sejumlah rekening yang tidak wajar oleh beberapa perwira tinggi Polri dan diduga berasal dari hasil korupsi.

Selain artikel "Halo 'Rekening Gendut"” yang mengulas korupsi di lembaga penegak hukum (yudikatif), ilustrasi no 10 (Kompas 9/11/2011) sangat gamblang memperlihatkan praktik korupsi di lembaga negara lainya, yaitu korupsi di lembaga peradilan. Dengan judul artikel opini "Resentralisasi Pengadilan Tipikor?", penulis mengulas masalah tentang ide resentralisasi pengadilan tipiko oleh sebagian kalangan karena banyaknya putusan bebas oleh pengadilan tipikor di daerah. Menelaah ilustrasinya yang menampilkan dua figur orang seperti figu seorang hakim dan figur seorang terdakwa yang saling berhadapan. Tangan kir sang hakim sedang memegang palu dengan ekspresi akan membuat putusan pengadilan, tapi tangan kanannya sedang berjabat tangan dengan terdakwa di bawah meja. Gambar ini dapat dimaknai bahwa putusan hakim sangat dipengaruh oleh terdakwa dan ada kerja sama antar keduanya. Kerja sama ini ditengara sebagai praktik suap kepada hakim. Jadi, pratik suap yang memengaruhi putusan hakim, sehingga pesan dalam ilustrasi mengamplifikasi pesan dalam artikel sebab artikel tersebut tidak membahas masalah putusan bebas yang dilakukan hakim pengadilan tipikor di daerah yang dipengaruhi oleh praktik suap. Namun, ilustras ini menjadi penguat dari ilustrasi editorialnya (no 5) yang menampilkan transformasi palu pengadilan tipikor seperti sebuah penjara yang terbuka dan keluarlah dua figur orang yang bersayap dengan hidung seperti tikus yang membawa tas tertulis Rp. Ilustrasi editorial tersebut bermakna bahwa para koruptor sangat bergembira dengan putusan bebas yang diberikan oleh hakim pengadilan tipikor

Bila ilustrasi no 10 menggambarkan perilaku korup lembaga peradilan, ilustrasi no 7 menampilkan praktik korupsi pada birokrasi. Dengan judul artike opini "Kabinet Kleptokrasi", ilustrasi no 7 digambarkan dengan seseorang yang mengenakan jas dan memegang bendera putih sedang duduk. Namun, yang menarik adalah visualisasi aktivitas sang figur di bawah meja. Aktivitas tersebut menggambarkan perilaku korup menerima suap secara sembunyi-sembunyi yang diilustrasikan dengan boneka jari memegang sebuah kotak untuk mengisi amplop. Hubungan yang terbangun antara ilustrasi dengan teks artikel terlihat dibagian judul, isi/pembahasan khususnya pada ulasan "kasus-kasus korupsi dibeberapa kementerian, seperti di Kementerian Perhubungan, Kementerian Pemuda dan
Olahraga, Kementerian Pendidikan Nasional, Kementerian Kesehatan, dan kini manyangkut juga Kementerian Tenaga Kerja dan Transmigrasi.” Hubungan kuat terlihat pula di bagian penutup, apalagi judul artikel disebut pada bagian ini melalui pernyataan "Jika Presiden Yudhoyono tidak berusaha keras untuk menghentikan berbagai praktik korupsi di berbagai kementerian, bukan mustahil kabinet yang dipimpinnya akan dikenal sebagai 'Kabinet Kleptokrasi' karena diisi oleh para bawahan yang suka mencuri uang negara karena posisi politik mereka." Dari hubungan ini dapat diketahui bahwa posisi ilustrasi dalam rubrik sebagai penguat artikelnya.

Ilustrasi artikel opini lainnya (ilustrasi no 6, Kompas 12/11/2011) dengan judul artikel "Zaman Kleptolitikum" menjadi semacam sebuah konklusi atas fenomena mewabahnya korupsi yang menjangkiti peradaban Indonesia. Menurut penulis, kleptolitikum adalah "peradaban yang sesungguhnya tidak beradab akibat kleptomania yang menjangkiti kuasa politik dan hukum di negeri ini”. Dalam peradaban kelptolitikum, penampakannya kontradiksi. Walaupun tampak glamor, mewah, dan modern tapi pada dasarnya sama dengan peradaban zaman batu, dimana mata hati dan nurani menjadi membatu karena dipenuhi keserakahan, kerakusan, dan ketamakan, sehingga menghilangkan moral dan etika. Ulasan ini menjadi rujukan utama dari visualisasi ilustrasi yang menampilkan manusia purba mengenakan baju lurik dan berkaca mata hitam serta memikul karung uang. Ilustrasi memiliki hubungan dengan artikel sebagai penguat pesan untuk memberikan gambaran bahwa penampakan manusia pada zaman kleptolitikum adalah seperti pada ilustrasi. Visualisasi wajah figur orang seperti manusia purba di zaman batu. Sedangkan pakaian, kacamata hitam, dan karung berisi uang pecahan seratus ribu menandakan aksesoris yang digunakan oleh manusia modern.

\section{Struktur Representasi dan Ciri Informasi Visual Ilustrasi Opini}

Untuk melihat struktur representasi dan ciri visual ilustrasi opini korupsi yang dimuat Kompas selama periode 2011, peneliti menggunakan matriks representasional leksikal yang diadaptasi dari Neil Cohn (2007: 39). Adapun struktur representasinya dapat disajikan pada tabel berikut: 


\section{Tabel 2. Matriks Representasional Leksikal Ilustrasi Opini Kompa}

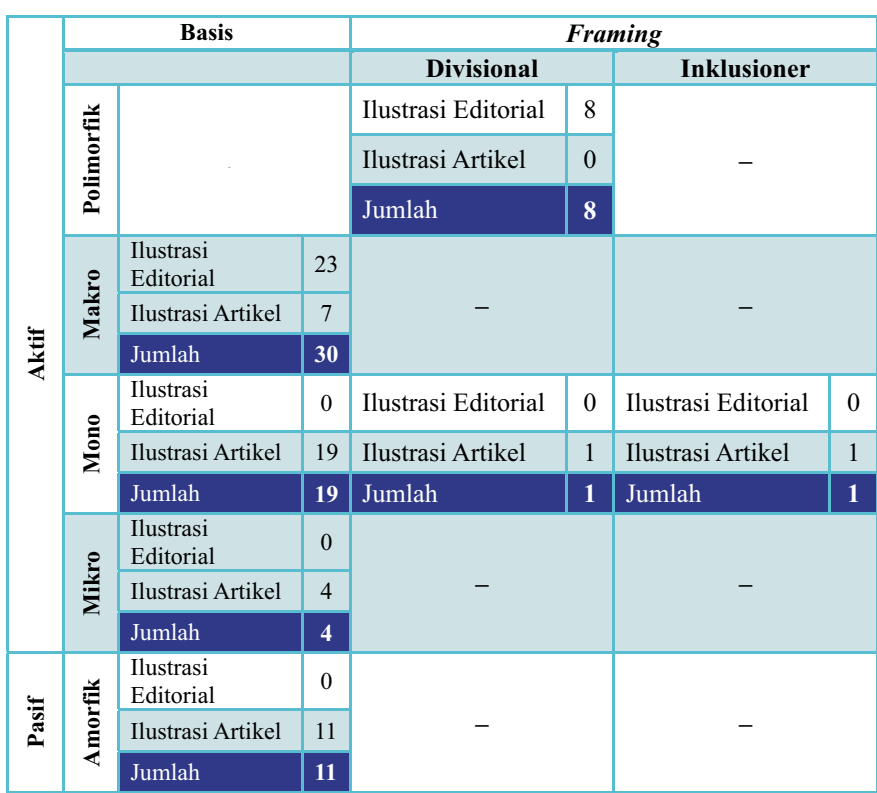

Melihat matriks di atas, mayoritas ilustrasi (63) masuk ke dalam representasi leksikal aktif dan hanya 11 ilustrasi yang masuk ke dalam representasi leksikal pasif. Hal ini berarti bahwa ilustrasi-ilustrasi dalam rubrik opini Kompas digambar dengan struktur representasi aktif khususnya ilustrasi editorial yang menempati dua level tertinggi matriks (polimorfik dan makro). Ada 8 ilustrasi editorial yang menempati level tertinggi aktif di panel divisional dari matriks representasi leksikal.

Ilustrasi-ilustrasi tersebut memanfaatkan panel untuk menyampaikan seluruh informasinya secara lengkap dan berbeda-beda antarpanel. Melalu penggunaan panel semacam ini, memudahkan khalayak untuk menangkap informasi yang disampaikan dalam ilustrasi. Delapan ilustrasi editorial yang masuk dalam panel divisional, semua informasinya ditampilkan minima memanfaatkan dua panel dan paling banyak empat panel. Misalnya, ilustras editorial karya Jitet, memanfaatkan dua panel untuk menyampaikan informasinya, baik itu perubahan suasana, ekspresi wajah maupun gerak tubuh. Atau ilustras editorial karya Didie SW yang menyampaikan informasi lengkapnya melalui empat panel, bahkan dengan panel-panel tersebut bukan hanya menampilkan perubahan suasana, ekspresi wajah atau gerak tubuh, tetapi juga dapat membuat sebuah narasi waktu.
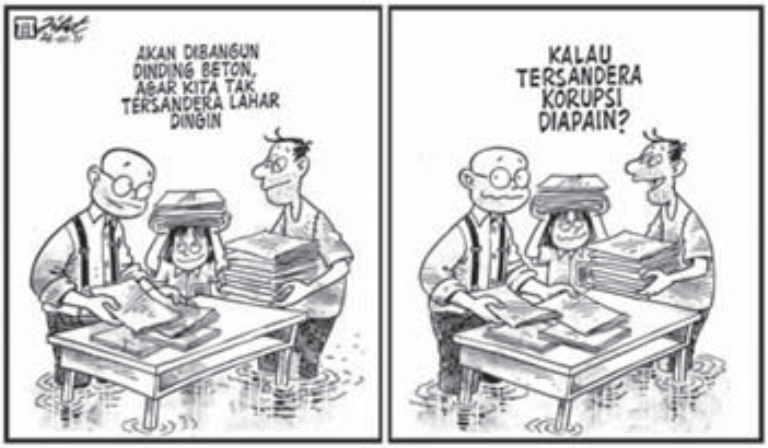

Gambar 5. Representasi Leksikal Aktif Polimorfik—Framing-Divisional Sumber: capture screen dari situs http://epaper.kompas.com/epaperkompas. php?v=1.0
Kiri: Ilustrasi editorial karya Jitet. Kompas Edisi 26 Januari 2011 (diakses 26/02/2012) Kanan: Ilustrasi editorial karya Didie SW. Kompas Edisi 12 Oktober 2011 (diakses 20/11/2011)

Level setingkat di bawah representasi aktif polimorfik adalah representasi aktif makro. Berbeda dengan 8 ilustrasi editorial sebelumnya yang masuk dalam kelompok pembingkaian — divisional, 30 ilustrasi di level makro ini masuk dalam panel basis atau dasar, yaitu menyampaikan seluruh informasi hanya dalam satu panel. Dari 30 ilustrasi, 7 diantaranya adalah ilustrasi artikel opini. Ilustrasi editorial pada gambar IV.9 (atas) menunjukkan adanya dialog antarfigur orang, tetapi semua ditampilkan hanya dalam satu panel, berbeda dengan ilustrasi di gambar IV.8 (atas) yang memisahkan teks dialog dan perubahan ekspresi wajah salah seorang figur dalam dua panel. Apalagi ilustrasi artikel opini (gambar IV.9 bawah) tanpa dialog, tapi menampilkan dua entitas aktifnya ke dalam satu panel. 

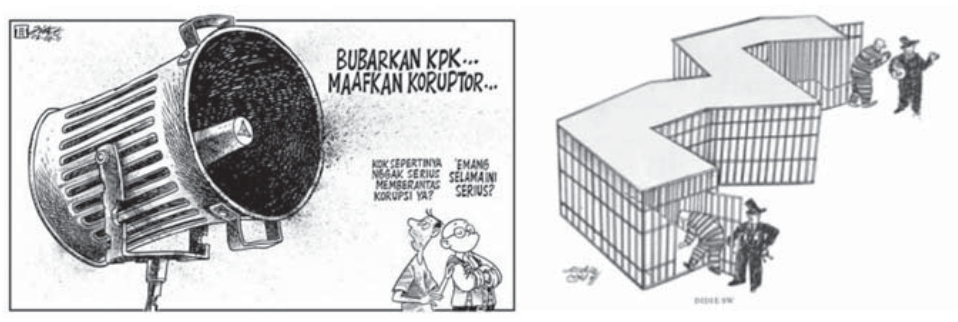

Gambar 6. Representasi Leksikal Aktif Basis-Makro

Sumber: capture screen dari situs http://epaper.kompas.com/epaperkompas.php?v=1.0 Kiri: Ilustrasi editorial karya Jitet. Kompas Edisi 3 Agustus 2011 (diakses 17/02/2012) Kanan: Ilustrasi artikel opini karya Didie SW. Kompas Edisi 5 Desember 2011 (diakses $10 / 12 / 2011)$

Basis-mono adalah level menengah dalam matriks representasi leksikal aktif. Seluruh ilusrasi-ilustrasi di level mono adalah ilustrasi artikel opini. Di leve ini pula semua panel matriks terwakili, yakni 19 ilustrasi basis-mono, 1 ilustrasi framing — divisional—mono, dan 1 ilustrasiframing — inklusioner - mono.
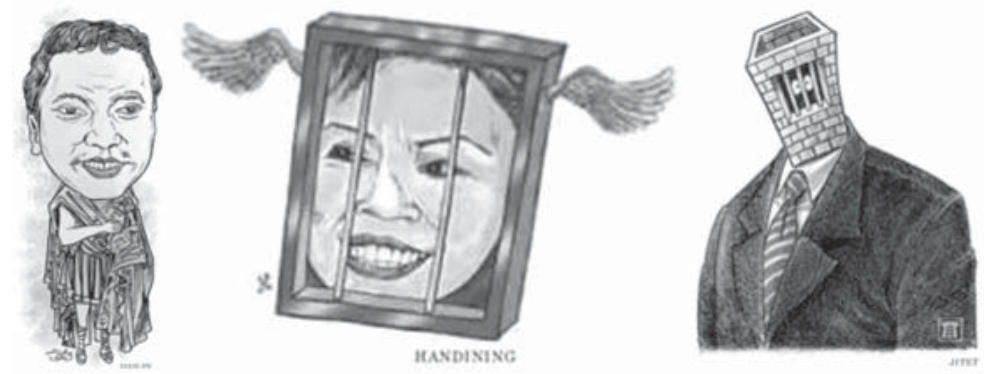

Gambar 7. Representasi Leksikal Aktif Basis-Mono, Framing-Divisional, Framing-Inklusioner

Sumber: capture screen dari situs http://epaper.kompas.com/epaperkompas.php?v=1.0 Kiri: Ilustrasi artikel opini karya Didie SW. Kompas Edisi 20 Januari 2011 (diakses 26/02/2012) Tengah: Ilustrasi artikel opini karya Handining. Kompas Edisi 30 Mei 2011 (diakses 24/02/2012) Kanan: Ilustrasi artikel opini karya Jitet. Kompas Edisi 24 Januari 2011 (diakses 26/02/2011)

Panel pertama (basis - mono), dalam satu panel hanya menggambarkan sebuah entitas tunggal. Ilustrasi Gayus Tambunan yang memakai jubah (gamba IV.10, kiri) merupakan contoh representasi leksikal aktif yang menggambarkan sebuah entitas tungal tanpa ada objek aktif lainnya. Selanjutnya, bidang framing - divisional, yakni membagi satu gambar menjadi bagian-bagian konstan. Ikon wajah Nunun Nurbaeti yang terbagi tiga (gambar IV.10, tengah), sebenarnya adalah satu kesatuan wajah figur Nunun. Namun, adanya jeruji besi menjadi bingkai yang membagi informasi (wajah) ke dalam tiga bagian, tetapi masih satu informasi yang konstan, yakni Nunun Nurbaeti. Ilustrasi ini menjadi contoh framing - divisional. Terakhir, panel framing - inklusioner. Inklusioner adalah panel menggunakan frame dalam frame. Gambar IV.10 (kanan) adalah contoh untuk bidang ini. Adanya tembok sebagai personifikasi visual, maka nilai informasi terletak pada tembok itu dan kualitas informasinya berada pada siluet mata dalam tembok, kotak yang memiliki jeruji yang membentuk frame paling kecil di dalam frame tembok dan frame ilustrasi keseluruhan.

Level mikro adalah level terendah dari matriks representasi leksikal aktif, karena informasi yang disampaikan kurang dari satu kesatuan dan sering dihadirkan dalam bentuk akhir close up. Di level ini terdapat 4 ilustrasi dan semuanya adalah ilustrasi artikel. Ilustrasi artikel opini KED160911168IAJT karya Jitet adalah salah contohnya. Ilustrasi tersebut menggambarkan close up tangan yang memegang alat tulis dengan beberapa tumpuk kertas suara di bawahnya. Penggambaran semacam ini membuat infromasi figur menjadi berukurang dan khalayak tidak tahu siapa figur tersebut.

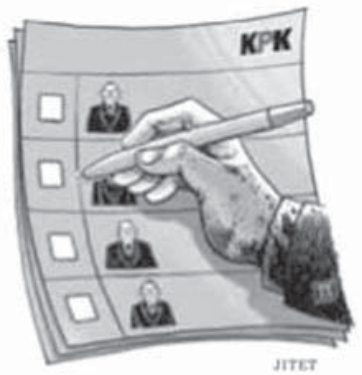

Gambar 8. Representasi Leksikal Aktif Basis-Mikro Sumber: capture screen dari situs http://epaper.kompas.com/epaperkompas.php?v=1.0 Ilustrasi artikel opini karya Jiet. Kompas Edisi 16 September 2011 (diakses 26/02/2012)

Level paling terendah dari matriks representasi adalah level pasif panel amorfik. Gambar dalam panel amorfik tidak memiliki entitas aktif apa pun, misalnya sebuah pemandangan atau lingkungan. Terdapat 11 ilustrasi aktikel opini yang masuk dalam level ini, yakni ilustrasi yang hanya menggambarkan sebuah 
benda mati atau tumbuhan. Misalnya seperti ilustrasi-ilustrasi berikut:
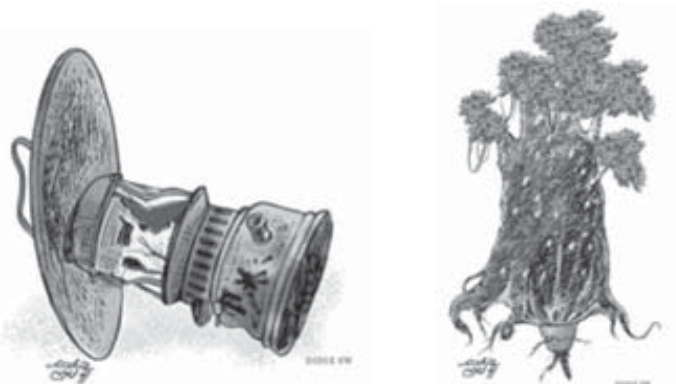

Gambar 9. Representasi Leksikal Pasif (Amorfik-Basis)

Sumber: capture screen dari situs http://epaper.kompas.com/epaperkompas.php?v=1.0 Kiri: Ilustrasi artikel opini karya Didie SW. Kompas Edisi 8 Agustus 2011 (diakses 17/02/2012) Kanan: Ilustrasi artikel opini karya Didie SW. Kompas Edisi 23 Desember 2011 (diakses

$$
\text { 25/12/2012) }
$$

Dari uraian di atas, dapat diketahui bahwa visualisasi ilustrasi dengan struktur representasi leksikal aktif dengan level polimorfik atau makro dapa memudahkan khalayak untuk menerima pesan yang diterima melalui ilustrasi karena kuantitas dan kualitas informasinya lengkap. Dan semua ilustrasi editoria untuk opini korupsi yang diterbitkan Kompas selama periode 2011 termasuk dalam struktur representasi aktif pada dua level tertinggi dari matriks representasi ini. Namun, terdapat juga beberapa ilustrasi dengan struktur representasi aktif di level terendah (mikro). Meskipun demikian, level mikro masih lebih baik dari pada struktur representasi leksikal pasif (amorfik) yang membutuhkan perhatian khusus untuk memahami pesan yang dibawa oleh ilustrasi.

\section{Pandangan Khalayak tentang Korupsi}

Perbincangan pertama adalah meminta pandangan dari sebelas orang khalayak pelibat tentang korupsi sebagai tanggapan setelah teks (ilustrasi) diperlihatkan kepada mereka. Teks yang diperbincangkan sama dengan ilustrasi (Gambar 3) yang dikaji maknanya pada bagian sebelumnya untuk melihat bagaimana wacana yang diproduksi media dikonsumsi khalayak berdasarkan makna yang mereka berikan kepada teks. Para pelibat dikodekan dengan PD untuk pelibat diskusi dan PW untuk pelibat wawancara. Sebagai panduan, dikemukakan pertanyaan berikut: Bagaimana pendapat Anda tentang korupsi dalam ilustrasi? Apa ciri visual dari pendapat Anda?
Dari hasil perbincangan, baik melalui diskusi kelompok fokus maupun wawancara dengan para pelibat, ditemukan beberapa wacana yang terbangun mengenai pandangan mereka tentang korupsi yang ditampilkan dalam ilustrasi. Secara ringkas, wacana yang terbangun dalam perbincangan seperti informasi grafis berikut:

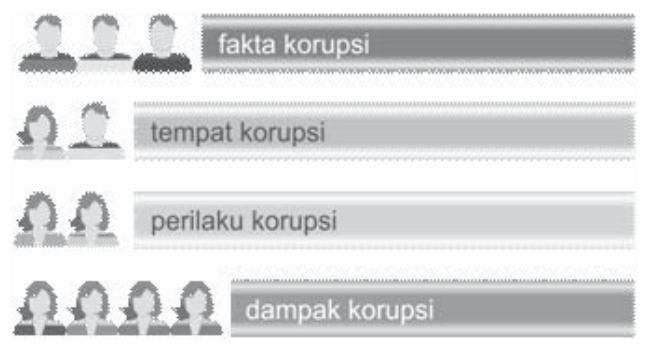

Gambar 10. Wacana yang terbangun tentang korupsi

Berdasarkan gambar di atas, ada empat wacana yang terbangun dari hasil interpretasi pelibat terhadap ilustrasi selama perbincangan, yakni wacana mengenai fakta korupsi, tempat korupsi, perilaku korupsi, dan wacana tentang dampak korupsi. Fakta korupsi terwacanakan dari tiga orang pelibat. Misalnya, wacana fakta korupsi dari pernyataan PD05 "pada era demokrasi perilaku korupsi semakin merajalela", "korupsi begitu besar" (PD06), dan "korupsi yang sudah melekat lama" (PD07). Wacana tersebut lahir dari objek visual yang sama, yaitu bendera. Pernyataan PD05 menyandingkan wacana fakta korupsi dengan wacana politik, di mana semakin merajalelanya korupsi justru terjadi di era demokrasi. Bila korupsi yang merajalela tidak memiliki ukuran pasti, PD06 meberikan ukuran pasti bagi korupsi, yaitu korupsi yang tengah terjadi begitu bersar. Korupsi yang merajalela dan begitu besar serta sudah melekat lama mengindikasikan bahwa secara sosial korupsi telah membudaya.

Berdasarkan teori wacana Laclau dan Mouffe, hal ini disebut dengan jalinan kesepadanan, yaitu wacana mengacu pada investasi penanda utama bendera (sebagai teks) dengan makna (yang diberikan pelibat). Semua wacana yang terbangun, fokus pengamatannya mengarah pada objek bendera dalam ilustrasi. Wacana-wacana ini disebut Fairclough dengan antarkewacanaan. Dari campuran antarkewacanaan kita dapat melihat unsur-unsur lain seperti lama peristiwa korupsi terjadi atau materi yang dikorupsi (misalnya, “...pemerintah Indonesia itu mata duitan... suka memakan uang negaranya sendiri” PD08). Selain wacana fakta korupsi, wacana lain yang terbangun dan mendominasi wacana- 
wacana yang ada adalah wacana dampak korupsi

Dari pernyataan PD01 dapat diketahui bahwa objek visual bendera yang kusam dan rusak dengan tiga tambalan tertulis Eksekutif, Legislatif, dan Yudikatif diartikulasikan sebagai dampak korupsi yang melibatkan tiga pilar demokrasi yang menciptakan ketidakpercayaan dan penghargaan terhadap lembaga-lembaga tersebut. Artikulasi objek visual yang sama dan lebih ekstrim dikemukakan PD02, di mana rakyat Indonesia semakin kacau karena pemerintah yang tidak mempedulikan rakyatnya. Atau PD03 mengartikulasikannya dengan semakin bobroknya Indonesia karena petingginya (di Eksekutif, Legislatif, dan Yudikatif) gemar melakukan korupsi. Sehingga korupsi telah "menghancurkan" sepert dalam pernyataan PD04. Tiga lembaga demokrasi menjadi penanda lahirnya wacana tempat orang-orang melakukan koruspsi.

Uraian di atas menunjukkan bahwa ilustrasi menghasilkan wacana yang memiliki antarkewacanaan tinggi. Antarkewacanaan yang tinggi ditandai oleh adanya perubahan dalam masyarakat (Jorgensen dan Phillips, 200: 151). Dari hasil analsis dapat disimpulkan bahwa wacana dalam ilustrasi menciptakan perubahan di masyarakat. Wacana fakta korupsi dan dampak korupsi menjadi sebuah bukti bahwa peristiwa korupsi yang terjadi di Indonesia beberapa tahun terakhir telah membawa perubahan pengetahuan dan kesadaran masyarakat bahwa korupsi dapat menghancurkan sendi-sendi berbangsa dan bernegara.

\section{Model Konstruksi Wacana Visual}

Berdasarkan ulasan di atas, dapat dilihat cara ilustrator menggunakan dan mengolah sumber daya semiotik dalam sebuah ilustrasi untuk membawa pesan media yang ditujukan kepada khalayak, baik melalui tata ungkap visual maupun tata ungkap verbal. Kedua tata ungkap diolah sedemikian rupa agar pesan yang dibawa mudah dimengerti dan dipahami khalayak. Dari makna yang terungkap, ilustrasi dapat memiliki hubungan dengan dengan teks artikel yang terdapat dalam rubrik opini, tetapi juga dapat berdiri sendiri tanpa bergantung pada teks manapun. Ada tidaknya relasi yang tercipta antara teks visual (ilustrasi) dengan teks verba (artikel) dapat menentukan posisi ilustrasi dalam rubrik. Setidaknya ada dua karakteristik posisi yang ditemukan, yakni posisi dependen (bergantung) dan posisi independen (mandiri).

Pada posisi dependen, ilustrasi memiliki hubungan dengan teks artikel, baik hubungan langsung dengan bagian judul, lead, pengantar, isi, maupun bagian penutup artikel atau hubungan terjalin hanya melalui salah satu bagian saja Sebaliknya, posisi independen, ilustrasi tidak memiliki hubungan sama sekal dengan teks artikel, sehingga pesannya dalam rubrik menjadi mandiri. Nilai pesan dalam ilustrasi ditentukan oleh kuantitas dan kualitas informasi yang ditampilkan, maka pemahaman struktur representasi menjadi penting. Disadari atau tidak, pendayagunaan sumber daya semiotik menentukan struktur representasi leksikal yang digunakan untuk menyampaikan informasi. Para ilustrator Kompas cenderung menggunakan representasi leksikal aktif untuk pesan visualnya khususnya pesan dalam ilustrasi editorial. Akan tetapi, representasi leksikal pasif juga digunakan ilustrator untuk menyampaikan pesan khususnya pesan pada ilustrasi artikel opini.

Pada tingkat wacana, terjadi perbedaan ditingkat produksi dan tingkat konsumsi. Pada tingkat produksi, wacana visual ditentukan media (melalui ilustrator) berdasarkan konteks situasi sosiokultural yang sedang terjadi dimasyarakat dan penentuan elemen-elemen visual yang ditampilkan dalam ilustrasi. Sedangkan pada tingkat konsumsi, khalayak lebih terfokus pada elemen visual apa yang ditampilkan dan bagaimana ia ditampilkan. Dalam penelitian ditemukan bahwa khalayak mengkonstruksi wacana yang ditampilkan dalam visual ilustrasi melalui identifikasi objek visual yang menarik perhatiannya. Kecenderungan pengidentifikasian objek lebih banyak dilakukan khalayak pada objek yang memiliki ciri khusus dalam komposisi visual yang ditampilkan, sehingga secara tata bahasa visual, makna yang dihasilkan dari proses identifikasi tersebut adalah makna komposisional. Proses pengonstruksian wacana visual ini dapat digambarkan melalui model di bawah ini:

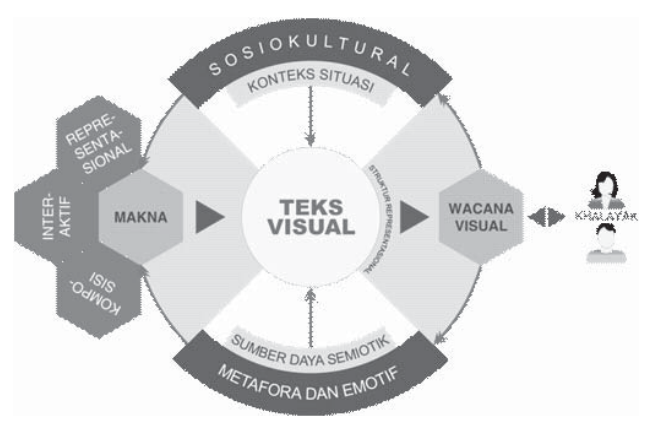

Gambar 11. Model Proses Konstruksi Wacana Visual

Anak panah dari konteks situasi dan sumber daya semiotik menunjukkan bahwa teks visual dihasilkan dari penafsiran media massa terhadap fakta sosial yang sedang terjadi dan mewujudkannya melalui penggunaan sumber daya semiotik. Pengolahan dan pegelolaan sumber daya semiotik dapat dilihat dari penggunaan dan penyusunan tanda-tanda dalam teks visual yang dijadikan sebagai alat pembawa pesan. Penggunaan tanda-tanda tersebut tidak terlepas dari 
pengetahuan khalayak tentang tanda itu. Menurut Hodge dan Kress (1988: 18) tanda-tanda tidak dapat dipisahkan dari bentuk-bentuk konkrit hubungan sosial (van Leeuwen, 2005: 3). Dalam penelitian ini, teks visual yang dimaksud adalah ilustrasi dalam rubrik opini Kompas, yaitu ilustrasi editorial dan ilustrasi artike opini. Sebagai hasil interpretasi Kompas terhadap fakta yang terjadi di masyarakat, ilustrasi menjadi metafora visual dari realitas yang ada dibaliknya. Secara khusus diungkapkan Sunarto (2005: 213), kemunculan metafora dan sikap emotif pada kartun editorial terlihat dari peranannya merelasikan situasi politik dan nila budaya, kerena kartun dilahirkan dari situasi sosial, mewakili kelompok politik untuk menyampaikan aspirasinya. Di mana sistem nilai yang berlaku dalam suatu kebudayaan tertentu menjadi pertimbangan aspirasi itu disampaikan. Hal in menunjukkan bahwa metafora dan sikap emotif menjadi kekuatan ilustrasi sebagai teks visual.

Ilustrasi adalah bahasa yang digunakan media massa untuk mengkomunikasikan pesan kepada khalayak sasaran melalui visual atau dapa disebut sebagai bahasa visual media massa. Melalui bahasa visual ini media berkomunikasi dengan khalayak. Bagi Kress dan van Leeuwen (2006: 41-42), aga dapat berfungsi sebagai sistem penuh komunikasi, visual, seperti semua modus semiotik harus melayani kebutuhan representasional dan persyaratan komunikasional. Dengan mengadopsi metafungsi dari Halliday untuk desain visual, keduanya berpendapat bahwa bahasa visual mempunyai metafungsi ideasional, interpersonal, dan teks. Metafungsi ideasional, elemen-elemen dalan ilustrasi sebagai modus semiotik harus mampu mewakili aspek dunia seperti yang dialami oleh manusia. Dari metafungsi ideasional kita dapat mengamati struktur naratif visual yang ditampilkan dan struktur konseptual antara objek yang satu dengan objek lainya serta objek dengan viewer (khalayak). Dalam metafungs interpersonal, modus apapun dalam ilustrasi harus mampu untuk mewakil hubungan sosial tertentu antara produsen tanda (media), viewer (khalayak), dan objek yang diwakili. Sedangkan metafungsi teks, setiap modus dalam ilustrasi harus memiliki kapasitas membentuk teks, keterpaduan tanda-tanda kompleks baik secara internal satu sama lain maupun eksternal dengan konteks dan untuk apa mereka diproduksi. Kress dan van Leeuwen (2006: 43) mengungkapkan, pengaturan komposisi yang berbeda memungkinkan terwujudnya makna teks yang berbeda. Gambar dalam tata bahasa visual berfungsi sebagai titik tolak atau jangkar untuk pesan. Dari ketiga metafungsi tersebut, maka teks visual ilustras menyediakan tiga makna yang dapat digunakan untuk memahami pesan dibalik tanda-tanda dalam ilustrasi, yakni makna representasional, makna interaktif, dan makna komposisi. Ketiga makna ini berelasi dengan konteks situasi dan sumber daya semiotik.
Nilai informasi yang menggambarkan peristiwa dalam tampilan ilustrasi bergantung pada struktur representasi leksikal yang digunakan ilustrator. Berdasarkan struktur representasi leksikal (Cohn, 2007: 39) terdapat dua struktur dengan dua panel, yakni struktur representasi leksikal aktif dan pasif. Masingmasing struktur terdiri dari panel informasi basis dan framing (divisional dan inklusioner). Pada struktur leksikal aktif terdapat empat panel yang menampilkan peristiwa secara berbeda. Keempat panel tersebut adalah panel polimorfik, makro, mono, dan mikro. Sedangkan struktur representasi leksikal pasif hanya terdapat satu panel, yakni panel amorfik. Struktur aktif--basis--polimorfik merepresentasikan peristiwa dalam batas bingkai tunggal melalui pengulangan bentuk badan tunggal pada tahap yang berbeda dari suatu tindakan. Misalnya, menggambarkan seseorang sedang yang berjalan dengan beberapa objek orang. Struktur aktif--framing--divisional--polimorfik, informasi peristiwa direpresentasikan dalam beberapa panel (seperti Gambar 5). Representasi peristiwa yang menggunakan frame dalam frame dengan menampilkan salah satu aktivitas dalam frame adalah struktur aktif-framing - inklusioner-polimorfik. Ciri visual pada frame terdalam adalah close up objek tujuan. Panel polimorfik adalah level tertinggi dalam menyampaikan informasi pada struktur represetnasi leksikal aktif.

Panel makro adalah level satu tingkat di bawah level polimorfik. Pada level makro representasi peristiwa mengandung lebih dari satu aktivitas dengan ciri visualnya digambarkan secara long shot. Pada struktur aktif-basis-makro, semua elemen ditampilkan dalam satu panel (lihat Gambar 6). Struktur aktif - framing - divisional — makro menampilkan satu kesatuan aktivitas dalam dua panel. sedangkan inklusioner membuat frame secara close up pada bagian kepala objek orang dan objek pendukungnya. Di bawah panel makro adalah panel mono yang hanya menggambarkan sebuah entitas tunggal dengan ciri visualnya digambar long shot atau medium shot. Struktur aktif-basis-mono, objek orang digambar secara tunggal dalam satu panel. Satu informasi, misalnya, close up wajah yang dibagi ke dalam beberapa panel adalah contoh dari struktur aktif--framing--divisional--mono. Pada struktur aktif--framing-inklusioner-mono, terdapat sebuah frame di bagian tertentu, misalnya, bagian mata objek orang untuk menegaskan informasi di bagian itu (lihat Gambar 7).

Level terendah dari struktur representasi leksikal aktif adalah panel mikro. Peristiwa dalam panel ini tampil kurang dari satu kesatuan informasi dan kadang ditampilkan dalam bentuk pengakhiran. Ciri visualnya objek aktif ditampilkan dengan cara extreme close up. Struktur aktif-basis-mikro menampilkan informasi dalam satu panel, framing - divisional menampilkan dalam dua panel, dan inklusioner menampilkan informasinya dalam satu panel, tetapi informasi pentingnya terdapat frame (Gambar 8). Dengan cara penyampaian pesan hampir 
sama dengan struktur representasi leksikal aktif, struktur pasif menampilkan gambar yang tidak memiliki entitas aktif apapun. Misalnya, gambar suasana lingkungan, benda mati, atau tumbuh-tumbuhan (lihat Gambar 9).

Melalui struktur representasi ini, wacana (visual) media massa dihadapkan dengan khalayak untuk dikonsumsi sebagai pratik kewacanaan sekaligus praktik sosial. Wacana visual yang terbangun dari khalayak dipengaruhi oleh wacana yang dibangun oleh teks melalui representasi visual dengan konteks situasi tertentu dari sumber daya semiotik yang digunakan. Cara mengidentifikas tanda dan memaknainya menetukan wacana apa yang akan terbangun dari interpretasi khalayak terhadap teks. Kress dan van Leeuwen menyatakan bahwa perbedaan komposisi berpotensi terciptanya makna teks berbeda, tapi pada kenyataannya, ketika khalayak mengonsumsi teks visual, cara mengidentifikas objek memegang peran penting atas perbedaan terciptanya makna teks. Faktor pengetahuan dan pengalaman khalayak juga menentukan perbedaan interpretasinya terhadap teks. Namun, kemampuan objek merepresentasikan peristiwa yang pernah dialami manusia (metafungsi ideasional) dapat mengurangi tajamnya perbedaan interpretasi. Hal ini terbukti saat peneliti mengumpulkan data dari khalayak melalui diskusi kelompok fokus dan wawancara.

Dengan pelibat yang heterogen dengan latar belakang pengetahuan dan pengalaman yang berbeda dapat mewujudkan hasil interpretasi yang sama terhadap objek yang sama, walaupun dengan redaksional yang berbeda. Meskipun demikian, tidak jarang juga ada objek yang sama diinterpretasi secara berbeda dan ada objek yang berbeda menghasilkan interpretasi yang sama. Dari kenyataan tersebut, perbedaan atau kesamaan hasil interpretasi dipengaruhi oleh objek mana yang terlebih dahulu diidentifikasi dan diinterpretasi oleh khalayak. Bila wacana visual menjadi pengetahuan masing-masing individu dan terkonstruksi secara sosial, maka efek yang ditimbulkan dari wacana adalah perubahan struktu pengetahuan masyarakat dan pada akhirnya dapat menciptakan sumber daya semiotik yang baru atau dalam pandangan van Leeuwen disebut inovasi semiotik.

\section{PENUTUP}

Paparan di atas memberi pemahaman bahwa makna ilustrasi yang dihasilkan dari interpretasi diperoleh melalui makna representasional, makna interaktif, dan makna komposisi dengan membaca tata ungkap verbal maupun visual dalam teks visual ilustrasi. Secara umum, relasi antarteks (visual dan verbal) cenderung saling berhubungan dengan posisi teks visual sebagai pelengkap, penguat, dan pendukung teks artikel. Informasi yang ditampilkan dalam ilustras lebih banyak menggunakan struktur representasi leksikal (visual) aktif khususnya ilustrasi editorial dibanding beberapa ilustrasi artikel opini yang menggunakan struktur representasi leksikal pasif. Untuk struktur aktif, panel polimorfik menempati level tertinggi dalam struktur. Ada beberapa ilustrasi yang menggunakan panel ini, terutama panel framing--divisional yang merepresentasikan peristiwa ke dalam beberapa panel gambar. Selain panel polimorfik, sebagian besar ilustrasi editorial menggunakan panel makro, sebagian besar ilustrasi artikel opini menggunakan panel mono dan mikro. Sedangkan hanya sebagian kecil dari ilustrasi artikel opini yang menggunakan panel amorfik dalam struktur representasi leksikal pasif. Penggunaan struktur tersebut menentukan kuantitas dan kualitas informasi yang disampaikan. Cara khalayak melakukan interpretasi terhadap teks visual ditentukan oleh tanda awal yang ia identifikasi. Tanda yang memiliki ciri khusus atau yang menarik perhatian dalam komposisi visual cenderung menjadi tanda yang digunakan khlayak untuk membangun wacananya. Selain itu, faktor pengetahuan dan pengalaman khalayak juga turut memengaruhi hasil interpretasi mereka tehadap teks serta relasi yang mereka bangun di dalam teks pada saat teks itu dikonsumsi.

\section{DAFTAR PUSTAKA}

Aditia, P. 2008. Ilustrasi Cerpen Kompas Periode 2002-2007: Ilustrasi Cerpen Isa Perkasa, Tisna Sanjaya, Nyoman Erawan, dan FX Harsono. Tesis Program Studi Magister Desain Institut Teknologi Bandung. Bandung: Program Studi Magister Desain FSRD ITB.

Barbatsis, G. Reception Theory, 271-293 dalam Smith, K., Moriarty, S., Barbatsis, G., dan Kenney, K. Eds, Handbook of Visual Communication: Theory, Method, and Media. London: LEA Publishers.

Cohn, N. 2007. A Visual Lexicon. The Public Journal of Semiotics. Dari http://www.emaki.net/essays/visuallexicon.pdf, diakses pada 20 Maret 2011.

Danesi, M.. 2009. Dictionary of Media and Communications. New York: M.E. Sharpe.

Denzin, N.K. dan Lincoln, Y.S. 2009. Handbook of Qualitative Research. (terj) Dariyatno, Badrus Samsul Fata, Abi, John Rinaldi. Jakarta: Pustaka Pelajar.

Eriyanto. 2009. Analisis Wacana: Pengantar Analisis Teks Media. Yogyakarta: LKIS.

Jorgensen, M. dan Philips, L. 2002. Discourse Analysis as Theory and Method. London: Sage Publications.

Kress, G. dan van Leeuwen, T. 2006. Reading Images : The Grammar of Visual Design Second Edition. New York: Routledge.

Kusmiati R., A. 1999. Teori Dasar Desain Komunikasi Visual. Jakarta: Djambatan.

Rivers, W.L., Jensen, J.W., dan Peterson, T. 2008. Media dan Masyarakat Modern (terj) Haris Munandar dan Dudy Priatna. Jakarta: Kencana 
Rose, G. 2001. Visual Methodologies: An Introduction to the Interpretation of Visual Materials. London: Sage Publications.

Santoso, A. 2008. Jejak Halliday dalam Linguistik Kritis dan Analisis Wacana Kritis. Jurnal Bahasa Dan Seni, Nomor 1, Februari 2008, halaman 2-15.

Smith, K., Moriarty, S., Barbatsis, G., dan Kenney, K. Eds, Handbook of Visual Communication: Theory, Method, and Media. London: LEA Publishers.

Sobur, A. 2009. Analisis Teks Media: Suatu Pengantar untuk Analisis Wacana, Analisis Semiotik, dan Analisis Framing. Bandung: Rosda.

Sumadiria, AS.H. 2009. Menulis Artikel dan Tajuk Rencana: Panduan Praktis Menulis \& Jurnalis Profesional. Bandung: Simbiosa Rekatama Media.

Sunarto, P. 2005. Metafora Visual Kartun Editorial Pada Surat Kabar Jakarta 1950-1957. Disertasi Program Studi Ilmu Seni Rupa dan Desain. Bandung: Program Studi Magister Desain FSRD ITB.

Tabrani, P. 2009. Bahasa Rupa. Bandung: Kelir.

Triandjojo, I. 2008. Semiotika Iklan Mobil Di Media Cetak Indonesia. Tesi Program Pascasarjana Universitas Diponegoro. Semarang: Program Pascasarjana UNDIP

Van Leeuwen, T. 2005. Introducing Social Semiotics. Ney York: Routledge.

Vivian, J. 2008. Teori Komunikasi Massa Edisi Kedelapan (terj) Tri Wibowo BS. Jakarta: Kencana.

\section{MUSIK DAN PEMATANGAN DINI JIWA ANAK}

Cipto Budy Handoyo

Fakultas Bahasa dan Seni Universitas Negeri Yogyakarta

\section{Abstract}

Music cannot be separated from human life, and it has been attached to people from generation to generation in all periods of time. Therefore, music logically influences human life as the civilization develops both in positive and in negative ways. The negative influences can cause the human beings' "early maturity". Commonly, negative influences have the power to affect people more easily, and this also happens in music. Music can easily inspire people, especially the young, in a negative way. For example, when children enjoy a certain kind of music with al its negative performance and style, they will be easily stimulated by what they see. Thus, people generally expect to gain the positive effects from music. In doing so, there is a huge responsibility for us to think about the way music can give positive contributions especially for the young. In this case, we should optimistically guide children to choose the right kinds of music for them so that we can help them develop their mind for their bright future.

Keywords: to prevent, early maturity

\section{PENDAHULUAN}

Fenomena musik mampu mematangkan jiwa anak secara dini telah cukup lama terjadi di negara kita Indonesia. Dari waktu ke waktu musik dalam hal ini musik yang disajikan beserta penyanyinya yang telah dikemas dalam suatu media kaset, CD, VCD, dan sebagainya, benar-benar telah berbuat banyak terhadap manusia. Pernyataan tentang pengaruh musik terhadap manusia telah lama dikatakan Karolyi (1965 : 11) bahwa musik berbuat banyak bagi manusia. "Perbuatan" musik terhadap manusia yang telah amat banyak ini antara lain : manusia menjadi terhibur, manusia menjadi kaya raya (bagi penyanyi dan produser yang sukses), menjadi tak sadarkan diri (seperti pada Kesenian Jatilan/Kuda Kepang di Jawa), dan bagi manusia yang masih kecil (anak : terutama anak seusia TK-SD): jiwanya telah banyak dipaksa menjadi "matang" secara dini, dan masih banyak "perbuatan" yang dilakukan oleh "makhluk" yang dinamakan Musik. 